\title{
THE EFFECTIVENESS OF A COUNSELING PROGRAM TO REDUCE ANXIETY AMONG A SAMPLE OF FEMALE STUDENTS
}

KEY WORDS:

\section{Wisal Elbasheer Ibrahim} (Application of the National Fund for StudentWelfare) Khartoum State

albahth ean barnamaj libarnama arshada litar qalaq alhasan ladaa eayinat min alttalibat almutafawiqat bikatbat alqismat altaeimati. min 'iiedad albahitha. tama tahlil natayij albahth bi'iistikhdam eadad min al'asalib al'iihsayiya (nsb) 'iilaa' an takun wa'iikhtibar (t) lieaynatayn mustaghilatayn, watawasalat albahithat lilnatayij alttalit: tujad furuq dalat ahsayyaan bayn mutawasitat darajat 'afrad almajmueat altajribat. tujad furuq dalat ahsayyaan bayn mutawasitat darajat 'afrad almajmueat altajribiat, wamutawasitat darajat' afrad almajmueat aldaabitat, ealaa miqyas albahth ean almajmueat lisalih almajmueat aldaabat

\section{INTRODUCTION:}

Abu Bakr Morsi (1997) asserts that undergraduate students impose many demands and challenges and failure to face them leads to a set of negative psychological and social problems, anxiety, depression and fears.

Conflicts are an essential element of our lives and all of our personalities are different, and accordingly different beliefs, values, perspectives, what people like and dislike. Some conflicts are difficult to confront, sometimes puzzling, especially if you take the subject personally and you are a very sensitive person. However, the outcome of a conflict can be a positive outcome, as it can help you create new ideas to learn from others, understand yourself better and improve your communication skills. Learning how to cope with and cope with conflicts is a very important life skill in the world full of differences and conflicts in which Mohamed Ibrahim Eid lives, 2005, 134).

Young people are the backbone of any progress, development and prosperity in the lives of peoples and nations. This is because the youth stage is the brightest and most powerful stages of life in human life, as it is a period of brilliance and appearance on the stage of life events. It is a period of work, giving, vitality and activity, it is a period of strength, health, creativity, pursuit, movement and intellectual development to keep pace with the new in all areas. He often does not find the right environment to invest all these energies and finds himself facing challenges and facing some of the psychological and social problems that haunt him and worry him (Taher Ammar (2013)).

\section{THE STUDY PROBLEIM :}

In light of the development and modernization of all aspects of the physical and technical educational process the student remains the most important aspects of this process, and that their role is essential in the development and improvement processes, and faces students in general and excel at the University in particular from many circumstances related to the nature and type of excellence, and this is linked to the personality of the student and methods of socialization of a student, Therefore, they must have the appropriate factors and conditions for success, excellence and academic excellence during their enrollment in the university. Unqualified gifted university residence of

The study problem can be crystallized in answering these questions- Are there statistically significant differences between the mean scores of the experimental group and the mean scores of the same group on the envy anxiety scale, before the test and several in favor of tribal application.

- Are there statistically significant differences between the mean scores of the experimental group and the mean scores of the control group on the envy anxiety scale after applying the programs for the control group.

- There are no statistically significant differences between the mean scores of the experimental group and the mean scores of the same group, on the envy anxiety scale used after the follow-up period.

To identify the differences statistically significant between the mean scores of the experimental group members, and the mean scores of the same group on the envy anxiety scale, before the test and several in favor of tribal application.

- Recognize statistical differences between the mean scores of the experimental group and the mean scores of the control group on the envy anxiety scale after applying the programs for the control group.

- Identify the differences statistically significant between the mean scores of the members of the experimental group, and the mean scores of the members of the same group, on the scale of envy anxiety used after the followup period

\section{THE IMPORTANCE OF THEORETICAL STUDY:}

1 - To show the importance of the role played by the extension programs in reducing the anxiety of students who have an envy that affects the behavior of the student and her academic performance and her relations with those around her.

2 - The importance of this study lies in the interest in caring for the psychological side of the superior student, the side that has been neglected by a lot of research, and this category needs more studies and research as a category of responsibility for building nations and preparing generations, and interest in them to achieve returns to society than those of other wealth.

3 - It is possible that the results of this study will be the nucleus of other studies in the field of the provision of extension programs that enable the achievement of an integrated personality of the superior student in all its aspects Applied importance:

1- Providing some information about extension techniques that can be used to reduce the envy anxiety of female students to maintain their academic and selfcompatibility.

2 - benefiting workers in the field of education from the results of this study, in a way that allows the provision of appropriate psychological care for the superior students.

Providing a contribution in the methods of dealing with the phenomenon of envy academic excellence, by employing the technicians in this regard and taking advantage of the results of this research to provide a guide program to alleviate the

\begin{tabular}{c|c|c|c|}
\hline Submitted : $11^{\text {th }}$ Augusr,2019 & Accepted : 30 & Peptember,2019 & Publication : 15 \\
\hline th & November, 2019 & \\
\hline
\end{tabular}


anxiety of envy of the superior students and the impact of school.

\section{STUDY ASSUMPTIONS}

1- There are statistically significant differences between the mean scores of the experimental group and the mean scores of the same group on the envy anxiety scale, before the test and several in favor of tribal application. 2. There are statistically significant differences between the mean scores of the experimental group and the mean scores of the control group on the envy anxiety scale after applying the programs for the control group.

There are no statistically significant differences between the mean scores of the experimental group and the mean scores of the same group, on the envy anxiety scale used after the follow-up period.

The limits of the study Human limitations: Superior students National Fund for Student Welfare. Spatial Boundaries: National Fund for Student Welfare. Time Limits: First Semester and Second Semester 2016-2017

Study terms: Superior students: Their cumulative rates are high and honored

Envy: It is an emotional feeling of wishing the demise of power, achievement, property or advantage from another person and obtaining it, or the envious of the desire to demise it. It became a phenomenon that began to spread in the land, and became her arts and colors. Envy is the hatred of grace for others, and wishing its demise.

The causes of envy enmity and hatred among people are the causes of envy.

Types of envy:Wish the demise of grace from others to return to it is. He wishes the demise of grace from others if you did not return to him. If he is sick, he wishes everyone to be

SECOND: the extension program.

In this study, the program is based on a scientific basis, which includes a set of structured and planned activities, and set a specific timetable, aimed at reducing the psychological burnout of a sample of teachers, using some cognitive techniques, such as self-control, relaxation and meditation, and homework , To treat emotional rationality, some cognitive strategies, social support, job analysis and characterization (Aladdin Kafafi(2005) Objectives of the Program General Objectives: The main objective of the counseling program is to help female students of the National Fund for Student Welfare to alleviate feelings of envy.

Specific Objectives To provide students with the concept of significance, importance, goals, psychological counseling and feelings of fear of envy and the relationship between them. Students are skillfully aware of self-understanding, selfcontrol, self-change, and positive self-assurance to support their self-confidence. The definition of students thinking and stereotyping and then the skill to modify ideas and change irrational ideas. Training students to pay attention Social environment and how to participate in activities and maintain social relations based on respect and mutual trust of their social adaptation. - Training students on the skill of identifying needs within the limits of capabilities and the optimum independence of the possibilities of ownership of students the skill of endurance and wave attitudes impatient. Learning to solve problem-solving Planning a sound behavior Conformance The student begins to develop a special perception of herself and others.
THE MAIN CONSIDERATIONS TAKEN INTO ACCOUNT IN THE COUNSELING PROGRAM: -

Strengthening the counseling relationship between the psychological counselor and the students of the National Fund's housing is based on trust and mutual respect. Developing suitable content for the counseling program in a way that is suitable for the students of the whole housing Procedures for the implementation of the program sessions in terms of the number of sessions and their objectives and the duration of each session in a way that can have a positive impact on the students and thus reflects the effectiveness of the program counseling .Expand the means used to achieve the goals (lecture .Discussion .Modeling, ...)

Target age group in the advisory program: The target group are students for the accommodation of the National Fund for Student Welfare, between the ages of 17 - 25 years. Extension Program Strategies: The researcher using and adopting the following methods:. Group Counseling: Counseling a number of clients that are similar and disturbed together in small groups as happens in a group counseling (Al-Fahal 59: 2009. Individual Counseling: It is one person's face-to-face counseling at a time and its effectiveness depends primarily on the career counseling relationship (Alaa Kafafi 2003).

Religious Guidance: Guidance that is concerned with the formation of an integrated psychological state based on religious foundations and methods (Jawdat Said 2004,p. 120).

\section{INDICATIVE METHODS USED IN THE PROGRAM:}

1. Lectures: It is a simple and inexpensive method and has been proven effective in many extension programs. To provide simple information and phrases appropriate to the respondents about psychological counseling and its importance and in all aspects of academic and social life (2008, p. 66). Group discussion: The exchange of views on the subject of the lecture between the researcher and students on the one hand, and on the other between each other. Modeling Albert Pan Dura Bandura (1977) believes that most people learn new behavior by observing others,. Role play is a social education curriculum whereby a person is trained to represent aspects of skills (Ibrahim et al., 1993: 99). . Positive reinforcement: It is the provision of pillars (praise praise) for the correct answers and appropriate responses during the discussion. Psychodramaand follow-up and some miscon ceptions Psychodrama, or psychological drama, is one of the most popular and effective methods of group counseling. 7 . Homework: Homework is a key component of group counseling programs in the form of homework assignments, which are defined at each counseling session and reviewed at the beginning of each session to advance the counseling process (Monthly 2008: 203). Space and time: Time and space are important aspects of implementing the extension program. So you meet with the group once every week eachOn Saturday at 2:00 pm so that the meeting time is not more than an hour and a half and not less than one hour. Where the extension program is implemented is Khartoum State National Fund for StudentWelfare

Guidance session topics: Each session of the group mentoring program includes the following steps:

1. Start the session by reviewing the previous session except the first session

2. Discussion of homework in the previous session - discuss the subject and purpose of the session

3. Application of techniques and guidance methods summarize and close the session and give homework

Basics of selection of the extension program: studies related to the subject of treatment programs associated with envy. Research interest in the design of counseling programs taking into account the time span of the sample by choosing appropriate images of their age to take into account the 
preparedness and attention of the sample by choosing suitable vocabulary and phrases

Expand the means and techniques used to achieve the objectives of the sessions.

\section{PREVIOUS STUDIES:}

STUDY: Zeinab Mohammed Zein Al-Ayesh (1994):

\section{TITLE:}

"The Effectiveness of Therapy in the Meaning as a Guiding Approach in Reducing Some Behavioral Strikes in Adolescence".

This study aims to identify some of the problems and behavioral disorders experienced by a sample of university students The application of a counseling program according to the techniques of treatment in the sense to reduce the severity of these disorders, (100) university students from the faculties of King Abdul Aziz University in Jeddah, Saudi Arabia, whose age ranges between (18-21) years, and included an experimental research sample (40) university students It was divided into two equal groups, one experimental and one control, by (20). The results of the study resulted in the following:

The diagnosis and identification of a group of behavioral disorders in adolescence in the study sample, after the application of the counseling program, it became clear how great the contribution and effectiveness of treatment in the sense of reducing the severity of some behavioral disorders. , To 1.Study:Mario Rahal Ben Gerges (1998):

This study aims to identify the effectiveness of a counseling program based on the theory of treatment in the sense of reducing the level of neuroticism and the existential vacuum (experimental study on a sample of university students). Of the university students, the sample of the study included (155) female students and the tools of the study used were as follows: The measure of free from the symptoms of neuropathy (preparation / researcher) .The counseling program (preparation/researcher).Pal meaning of

TITLE:

"The Effectiveness of Therapy in the Meaning of Adjusting the Destination of Control among Visually Impaired Students This study aims to id On the normal and satisfactory personality traits of visually impaired students, and the program of treatment in the proposed sense (preparation / results of the study reached the following:

There is a positive correlation statistically significant between the point of internal control and characteristics of warmth, emotional stability, control and agitation.

5-Study: Ashraf Mohamed Abdel Halim AbdelWahab (2007): This study aims to develop a program. The study sample consisted of a final sample of (20) young men and women. Anxiety Death Scale (Preparation / Researcher), Target Test of Life (Preparation / Ismail Badr), and Sense Therapy Program (Preparationentify 6- Study: Atef Mossad Al-Husseini AlSherbini (2008):

This study aims to use a new indicative curve which is a sense therapy in an attempt to address the phenomenon of future anxiety. College was divided into two groups: the experimental group consists of (50) students,. The study tools included the following: The program of treatment in the sense (preparation / researcher) on some of the techniques, including:

SECOND:

Socratic Dialogue Technique Third: Future Anxiety Technique Parable Method Future Anxiety Scale (Prepared by /
Researcher)

\section{7-Studying Samar Salah Mahmoud El-Sayed (2010)}

Title: "The effectiveness of a counseling program in the sense to develop skills to deal with stress, which is a sample of teachers." It has already contributed to alleviating the envy of a sample of outstanding students, and has been instrumental in raising the level of skills to deal with envy anxiety.

\section{THE RESEARCHER VERIFIED THE VALIDITY OF THE SCALE AS FOLLOWS:}

Factor validity: where the researcher used factor analysis, using correlation coefficients between the sum of the scores of each dimension From the dimensions of the scale, between the degree as described in Gedo to the number (2).

Table (2) shows the correlation coefficient matrix between the total degree of envy anxiety dimensions and the total score of the scale

Total Degree Third Dimension Second Dimension First Dimension

- The first dimension

- 0,378 second dimension

- $0,3390,283$ Third dimension

- Total score

\section{Correlation coefficients are a function at the level of 0.01}

(A) VALIDITY OF THE SCALE: THE RESEARCHER VERIFIED THEVALIDITY OFTHE SCALE AS FOLLOWS:

The researcher extracted the terms of this measure from the previous studies that dealt with the subject of programs The researcher, through his work in the field of making excellence at the University, presented an open question about the envy anxiety and interviewed some students who are suffering. Already anxious envy for academic excellence.

1-The Honors

The scale was presented to (15) faculty members in the Department of Psychology, some Sudanese and Arab universities such as Hail University, Saudi Arabia, Sudan University of Science and Technology, Al-Jazeera University, Khartoum. In the light of the remarks of some of the judges (B) Scale stability: Scale stability is calculated in two ways:

\section{1- REAPPLY:}

The stability coefficient was calculated using the re-test method on a sample of (36) female students from different faculties from the colleges from which the study sample was selected. Cognitive (0.93) and the third psychological field $(0.87)$ and the value of the total stability coefficient $(0.94)$

\section{2- ALPHA CRONBACH METHOD:}

Stability was calculated in this way for the various factors of the scale and the whole scale on the same sample or the number of stability (36) and students, The value of the coefficient of stability for the physiological field (0.72) and the cognitive (0.79) and the psychological (0.78) and the value of the total coefficient of stability is equal to (0.86) and the stability is acceptable for the purposes of this study.

Second: Extension Program: (Prepared by the researcher): The advisory program that was used with the students of ten counseling sessions at the rate of two sessions per week, each of (60) minutes.

The researcher tried to benefit from the Kanfer test for selfcontrol and other cognitive behavioral methods.

The program included the following skills: self-monitoring self-assessment - self-reinforcement - stop and think. 
SESSIONS OF THE INDICATIVE PROGRAM: THE CURRENT PROGRAM INCLUDES A NUMBER OF SESSIONS, NAIMELY:

First Session: In this session, acquaintance with the situation is collected, and basic information about her life is collected. In which the situation lives

\section{SECOND SESSION:}

The main objective of this session is to establish a strong humanitarian and guiding relationship with the situation. Depth In the indicative relationship between the case and the treatment, the treatment reveals part of

This leads to making the relationship between them more humane, as the existential dialogue should take this simple non-artificial image, and that helps the situation to feel relieved, safe and confident in the treatment.

\section{THIRD SESSION:}

The aim of this session is to help the situation to cleanse the emotions and feelings associated with its fears and feelings of concern, therefore, the treatment leaves the situation a full opportunity to talk about itself and its own experiences and treatment only ask some simple questions to urge the situation to talk about its past experiences with envy, especially envy of those close Her hear her view causes envy

\section{FOURTH SESSION:}

In this session, the treatment aims to provide a clear picture of the treatment in the sense and the philosophy of this treatment, and the basic aspects that underpin it.

1. Freedom of human will and human responsibility for selfdetermination. The will of meaning is the fundamental motivation of man in life

2. Man is responsible for formulating realistic goals in his life. An existential vacuum is a spiritual crisis that must be confronted with courage

3. Be or not to be the editor of human existence.

\section{FIFTH SESSION:}

This session aims to clarify the truth of envy, and some aspects associated with it is not the end of human existence envy says in It is the beginning of another existence in another world that has its standards and systems, and how human envy has meaning. It gives life a value and meaning, and makes man seeks to invest every moment in his life there are some basic aspects are

- Envy exists, but not in a way that limits the activation and creativity of human causes of envy linked to human actions symptoms involving the meaning of the existence of the human that extends and succeeds if envy rights. Models and images of people who have pushed their lives for values and ideals.

Then put the treatment on the case Sal which is the meaning of your life? Or in another language what are your goals in life

\section{SIXTH SESSION:}

In this session, the students discuss the meanings and objectives formulated by each of them, in order to help each case to gain insight into the multiple meanings in life, not to train them not to think of death in excess, through the use of the technique of stopping intellectual reflection where the case is trained on Transforming the mindset of envy into other things related to life, such as the practice of meaningful activities such as reading in literature, or any other activities, whether artistic, musical, sports or social, with the situation not to stay alone in a vacuum because it helps to increase her thinking in Envy and fear of him, and that T. The first case of thinking in some aspects of provoking pleasure before she went to sleep.
7. SEVENTH SESSION:

In this session, students are trained to deal with their extreme fear and anxiety of envy in a more realistic way. These activities include:

Call an old girlfriend and meet her. - Meet a loved one. Meeting with a group of friends. -Visiting parents or boat

Listen to the Holy Quran. - Meet a new person. - Spending time helping the needy - Reading a new book or novel. Planning a trip or vacation. Memorize parts of the Holy Quran. Dumping into doing something loved. Imagine the pleasant events that will happen in the future

And follow up the situation to see the extent of their appetite for these activities.

\section{EIGHTH SESSION:}

In this session, the situation is helped to put a distance between them and their anxiety and fear of envy, using the technique of self-separation, where the situation helps to stand outside itself and look at itself as if it were someone else. Man is manifested in a spirit of fun because it has a unique ability to overcome fear and anxiety of envy and

\section{NINTH SESSION:}

In this session, the technique of Socratic Dialogue is used in order to help teachers to gain insight into the meaning of their lives. Think about and engage with envy.

\section{TENTH SESSION:}

In this session, students are discussed in the sense of suffering and that everyone has a share of pain and fear, and that pain is important in the refinement of human personality, and it is estimated that the human experience of the experience as much as his inner greatness, suffering creates a human challenge to reach the meaning of his life. The painful manifestation of the unique features of the human and highlight the deepest aspects of humanity, and the greatest forms of suffering fear and anxiety of envy, so treatment seeks to help the situation to understand the meaning behind envy, and the fear of the root from which stems from the responsibility of man to achieve his existence, as treatment here uses the approach story It features a number of symbolic stories to illustrate the meaning of suffering, pain, sadness and fear.

\section{ELEVENTH MEETING:}

This session aims to use the LOGO Drama, where the therapist brings the students together, and then the treatment asks one of them to imagine that her academic achievement was cut off from the university, what she wished to do in her life, what things she regretted did and what she wished. If you live longer than that, then the other students discuss the situation in the answer to these questions and then the treatment to comment on these group discussions, and discover the meaning in the situation, and then ask the treatment of each case to write a short story about a person injured and surrendered to en In a severe line he is afraid envy waiting for death What are his feelings? Why fear envy? What did he wish to do in his life?

\section{TWELFTH MEETING:}

The treatment in this session presents the stories written by the students and then comment on each story and clarify the contents of each story and the purpose of emphasizing the importance of the meaning of life.

\section{THIRTEENTH SESSION}

The current session is an extension of the previous session where the follow-up of the presentation of the stories of the requests and draw what is in them with emphasis on the importance of the challenge to create the meaning of life.vy 


\section{Manal Head and became life}

\section{FOURTEENTH SESSION:}

This session discusses the spiritual aspects of the students, in particular the performance of the religious duties and the extent to which the students are committed to performing and maintaining the five daily prayers, and emphasizing that envy reminds us of our responsibility and our actions to achieve our existence according to divine teaching and in the light of the orders and prohibitions derived from religion Religion plays a clear role in the sense of comfort and tranquility and reduce anxiety and fear.

\section{A table indicating the program sessions}

\begin{tabular}{|c|c|c|c|c|c|}
\hline Session number & Session objectives & Techniques used & \begin{tabular}{|l|}
$\begin{array}{l}\text { Duration of the } \\
\text { session }\end{array}$ \\
\end{tabular} & Session type & $\begin{array}{l}\text { Type of treatment } \\
\text { used }\end{array}$ \\
\hline First session & $\begin{array}{l}\text { Dating and gathering information } \\
\text { and data on the situation }\end{array}$ & personal interview & Hour & Individually & Behavioral therapy \\
\hline Second meeting & $\begin{array}{l}\text { Establish an indicative relationship } \\
\text { and bridge of trust with the situation, } \\
\text { and tune a positive trend towards the } \\
\text { program }\end{array}$ & Free interview & $\begin{array}{l}\text { An hour and a } \\
\text { half }\end{array}$ & Individually & Behavioral therapy \\
\hline Third Session & $\begin{array}{l}\text { Emotional cleansing of the feelings } \\
\text { of the situation and to identify its } \\
\text { experiences, especially those } \\
\text { related to envy and thinking about it }\end{array}$ & Emotional cleansing & Two hours & Individually & $\begin{array}{l}\text { Cognitive behavior } \\
\text { therapy }\end{array}$ \\
\hline Fourth Session & $\begin{array}{l}\text { Presentation of the philosophy of } \\
\text { treatment in the sense, concept, } \\
\text { foundations and objectives }\end{array}$ & $\begin{array}{l}\text { Refutation and } \\
\text { discussion }\end{array}$ & $\begin{array}{l}\text { An hour and a } \\
\text { half }\end{array}$ & collective & $\begin{array}{l}\text { Behavioral rational } \\
\text { treatment }\end{array}$ \\
\hline Fifth meeting & $\begin{array}{l}\text { Urging the situation to look for the } \\
\text { meaning of her life and satisfy her } \\
\text { need for a team to raise the sense of } \\
\text { emptiness of meaning to her }\end{array}$ & Discussion & $\begin{array}{l}\text { An hour and a } \\
\text { half }\end{array}$ & collective & $\begin{array}{l}\text { Cognitive- } \\
\text { behavioral therapy }\end{array}$ \\
\hline Sixth meeting & $\begin{array}{l}\text { Reduced thinking about anxiety in } \\
\text { general and death anxiety in } \\
\text { particular, and increased motivation } \\
\text { of students to seek meaning and get } \\
\text { engaged in an issue, as a message to } \\
\text { their status }\end{array}$ & Discontinuation & Two hours & collective & $\begin{array}{l}\text { Behavioral and } \\
\text { cognitive therapy in } \\
\text { the sense }\end{array}$ \\
\hline Seventh meeting & $\begin{array}{l}\text { Train the situation to deal with the } \\
\text { realistic concern about death and } \\
\text { feelings of emptiness }\end{array}$ & $\begin{array}{l}\text { Refutation and } \\
\text { discussion }\end{array}$ & Two hours & collective & $\begin{array}{l}\text { Behavioral rational } \\
\text { treatment }\end{array}$ \\
\hline Eighth meeting & $\begin{array}{l}\text { Training the case to overcome its } \\
\text { fear and anxiety of envy and } \\
\text { preoccupation with the practice of } \\
\text { some activities, whether artistic or } \\
\text { drawing or sports or social }\end{array}$ & Self-separation & $\begin{array}{l}\text { An hour and a } \\
\text { half }\end{array}$ & collective & Singing therapy \\
\hline Ninth meeting & $\begin{array}{l}\text { Provoke the situation to revisit her } \\
\text { life again, and search for goals and } \\
\text { meanings that fill her life }\end{array}$ & Socratic Dialogue & Two hours & collective & Treat in the sense \\
\hline Tenth meeting & $\begin{array}{l}\text { Highlight the meaning of pain, } \\
\text { sadness and suffering and how to } \\
\text { turn it into achievement, and discuss } \\
\text { the content of stories in order to } \\
\text { identify the meaning of each case }\end{array}$ & $\begin{array}{l}\text { Discussion Avatar } \\
\text { story }\end{array}$ & Two hours & collective & $\begin{array}{l}\text { Behavioral and } \\
\text { cognitive therapy in } \\
\text { the sense }\end{array}$ \\
\hline $\begin{array}{l}\text { Eleventh } \\
\text { meeting }\end{array}$ & $\begin{array}{l}\text { Students assess their lives and their } \\
\text { meanings, feel the meaning and } \\
\text { value of life, and have the } \\
\text { opportunity to exchange roles }\end{array}$ & $\begin{array}{l}\text { Drama Logo } \\
\text { Debate }\end{array}$ & Two hours & collective & $\begin{array}{l}\text { Behavioral and } \\
\text { cognitive therapy in } \\
\text { the sense }\end{array}$ \\
\hline Twelfth meeting & $\begin{array}{l}\text { Realistic perception of death and } \\
\text { highlight the value of life, then } \\
\text { identify each case on its strengths } \\
\text { and weaknesses, and deal with each }\end{array}$ & Group discussion & Two hours & collective & $\begin{array}{l}\text { Cognitive- } \\
\text { behavioral therapy }\end{array}$ \\
\hline $\begin{array}{l}\text { Thirteenth } \\
\text { meeting }\end{array}$ & Complete the previous session & Group discussion & Two hours & collective & $\begin{array}{l}\text { Cognitive- } \\
\text { behavioral therapy }\end{array}$ \\
\hline $\begin{array}{l}\text { Fourteenth } \\
\text { meeting }\end{array}$ & $\begin{array}{l}\text { Highlight the spiritual and religious } \\
\text { aspects of the situation }\end{array}$ & $\begin{array}{l}\text { Religious } \\
\text { Guidance }\end{array}$ & Two hours & collective & $\begin{array}{l}\text { Psychological } \\
\text { analysis and } \\
\text { cognitive } \\
\text { behavioral therapy }\end{array}$ \\
\hline
\end{tabular}

15. FIFTEENTH MEETING:

It is the final session, where the most important points are summarized in the program guide and emphasize the willpower to create meaning or rather discover it and emphasize the responsibility of the human responsibility for self-determination either to embark on a life effectively to achieve its existence or expect within the position of active prisoner of envy.

The program takes a period of three months and one month to continue. 


\begin{tabular}{|l|l|l|l|l|}
\hline $\begin{array}{l}\text { Fifteenth } \\
\text { meeting }\end{array}$ & $\begin{array}{l}\text { Summarize the most important } \\
\text { aspects of the program and } \\
\text { emphasize the importance of the } \\
\text { sense of the sense of life, and that the } \\
\text { concern of envy is overcome, and } \\
\text { each case can reshape its ideas and } \\
\text { beliefs again, and that each case } \\
\text { thinks what it gives to life and not } \\
\text { what it takes them, and emphasize } \\
\text { the optimistic view of life and the } \\
\text { future }\end{array}$ & $\begin{array}{l}\text { Refutation and } \\
\text { discussion }\end{array}$ & Hour \\
& & & & \\
\hline
\end{tabular}

\section{Study Results:}

First: the results of the first hypothesis and discussed: It states: "There are positive statistically significant differences in the level of envy anxiety and its dimensions between the experimental group and the control group after receiving the experimental group reconciliation program.'

To validate the hypothesis, the results of the experimental

\begin{tabular}{|l|l|l|l|l|l|}
\hline Experimental group & N & M & P & T value & Significance level \\
\hline Before the program & 18 & $4 ., 5$ & 2,75 & 3,107 & 0,01 \\
\cline { 1 - 4 } After the program & 18 & 3.75 & 1,38 & & \\
\hline
\end{tabular}

The results of the previous table indicated that there were statistically significant differences in the level of envy anxiety in the experimental group members before and after receiving the program at the level of envy anxiety in the university students. The researcher also confirmed the effectiveness of the counseling program effectively in reducing the level of envy anxiety among the outstanding students. group were compared with the results of the control group after receiving the experimental group indicative program by applying the anxiety test using T.Test test.

Table (1) Averages, standard deviations and the value of $\mathrm{T}$ for the experimental and control groups for envy anxiety test after receiving the experimental group

The researcher also confirmed the effectiveness of the counseling program in reducing the envy anxiety of the experimental and control group after the experimental group received the counseling program by using the $T$ test and table (3) illustrating this. Table (3) averages and standard deviations and the value of $\mathrm{T}$ for the envy anxiety dimensions of the experimental and control groups after the pilot group received the pilot program.

\begin{tabular}{|l|l|l|l|l|l|l|}
\hline the group & Dimensions & $\mathbf{N}$ & $\mathbf{M}$ & $\mathbf{P}$ & T value & Significance level \\
\hline Experimental & Physiological & 18 & 7,57 & 2,68 & 1,894 & 0,05 \\
\hline Control & & 18 & 6,38 & 2,054 & & \\
\hline Experimental & Cognitive & 18 & 20,84 & 5,61 & 1,986 & 0,05 \\
\hline Control & & 18 & 18,18 & 4,93 & 3,406 & 0,01 \\
\hline Experimental & Psychological & 18 & 8,63 & 2,68 & & \\
\hline Control & & 18 & 6,49 & 2,064 & & \\
\hline
\end{tabular}

The results of the previous table indicated that there are statistically significant differences at the level of confidence $(0.05)$ for the physiological and cognitive dimension and statistically significant differences at the level of confidence (0.01) in the psychological dimension for the benefit of the experimental group after receiving the proposed program

\section{SECOND: THE RESULTS OF THE SECOND HYPOTHESIS AND DISCUSSED:}

There are positive statistical differences in the level of envy anxiety and its dimensions between the pretest and post test in the students who have undergone the training program in

\begin{tabular}{|l|l|l|l|l|l|l|}
\hline Dimensions & Measurement & N & M & P & T value & Significance level \\
\hline Physiological & Tribal & 18 & 8,64 & 3,49 & 3,987 & 0,05 \\
\hline & after me & 18 & 3,47 & 2,48 & & \\
\hline Cognitive & Tribal & 18 & 36,84 & 1,27 & 1,386 & 0,05 \\
\hline & after me & 18 & 18,18 & 4,93 & & \\
\hline Psychological & Tribal & 18 & 6,47 & 2,62 & 0,01 \\
\hline
\end{tabular}

The results of the previous table indicated that there were statistically significant differences in favor of individuals who received the self-control counseling program to reduce the psychological stress level at the level of confidence (0.01) in the physiological and psychological dimension, while the differences were statistically significant at the confidence level. (0.05) in relation to the cognitive dimension and that achieves the validity of the assumption.

\section{DISCUSSION AND INTERPRETATION OFTHE RESULTS}

The study hypotheses have been achieved, and the results may be due to the improvement in reducing the level of envy the program to reduce envy anxiety (experimental group).To validate the hypothesis, the researcher calculated the differences, averages and standard deviations before and after applying the program to the experimental group, the results of which are shown in the following table:

Averages, standard deviations and the value of " $\mathrm{T}$ " in individuals

Experimental group before and after receiving the mentoring program

anxiety in the experimental group because they were affected by the program itself in terms of exercises and homework carried out by the experimental group in addition to the program aims to give the experimental group skills to help them reduce psychological stress The skills consisted of self-monitoring, self-assessment, self-reinforcement, stopping and thinking before conducting behavior, identifying the problem, identifying possible solutions in solving it, positive self-talk, positive self-affirmation, and reaching an individual with a high capacity of control. Many studies have indicated that the method of self-control is one of the effective methods used to reduce the stress of envy 
anxiety.These results are consistent with many studies. Like(Henley, 2004) and Charmahan (1991), Anslie (1996), and the results of this study concur with those of Morin (2001).

These results may be interpreted in light of the fact that selfcontrol exercises help the individual to reorganize cognitive, which leads to modify the patterns of self-talk and thus modify the abnormal behavior and conduct positive activities and set realistic goals and work to achieve.

Based on the above and through the results of the study and discussed the researcher recommends the following:

1 - The concern of envy is a big and serious problem that has a negative impact on the superior and their psychological state of society, and therefore negative impact on the educational and developmental process, which imposes the importance of addressing and trying to alleviate. Compare the self-control technique with other methods of reducing anxiety envy.

1 - the application of self-control with other psychological problems such as social conflicts and fear and failure to academic performance and problems of parental behavior.

2 - Trying to train faculty members of universities on the method of self-control in order to use with students to reduce the anxiety of envy when superiority, through some programs and counseling courses.

Training university students on how to apply self-control methods to themselves in order to develop their skills to achieve mental health and distinguish them with the signs of normalism, where students rely on their own efforts in the face of problems and the urgent need specific logical strategies on confrontation, which increases the feelings of helplessness for them, and may develop the means of detection Psychological problems increase the chances of early realization This result may indicate that the psychological needs of the age stages with the reality and cultural and social differences and this further weakens the level of psychological compatibility

The researcher pointed out that despite the fact that all the students who participated in the program in all their classes were exposed to the same conditions and the same reinforcements during the application of the counseling program.

FIRST: ARABIC REFERENCES: Al-Qalam, verse 5l: AlFalaq, verse: 5 .

- Ibn Manzoor (1414H), The Tongue of the Arabs (3rd ed.), Beirut:Dar Sader, p. 148, part 3. Acting.

-Jerjani (1983), Definitions (1st ed.), Beirut: Scientific Books House, p. 87.

Fatwa Center (28-2-2001), "Signs and Symptoms of the Envied and the Eye and Treating It", Islam Web, see it on 24-2-2017. Pts- Narrated by al-Zarqani, in the abbreviation of purposes, from Jabir bin Abdullah, page or number: 675, the summary of the ruling updated:

- Narrated by al-Albaani, in Saheeh al-Tirmidhi, from Abdullah bin Abbas, page or number:2060, true.

Ali bin Nayef (2011), Polite in the treatment of eye, touch and magic (lst ed.), Pahang:Dar Al-Mamour, pp. 44-46. Behave

- "The difference between hatred, envy, eye and elation", IslamWeb, 2-4-2011, accessed on 13-3-2017. Behave.

-Tabari (2000), Al-Bayan Mosque in the Interpretation of the Qur'an (1st ed.), Beirut:Al-Resala Foundation, p. 564, part 23.

Wah Ali ibn Abi Bakr al-Haythami, in the compound appendages and the source of benefits, from Abu Huraira, page or number: part 5, 184, hadeeth no: 8425 .

Narrated by Muslim, in Sahih Muslim, from Aisha, page or number: 39, part 4, hadeeth no: 1718.

Narrated by Ahmad ibn Hanbal, in Musnad, from Abdullah bin
Abbas, page or number: part 3, 125, hadith no: 2476

Wah Muslim, in Sahih Muslim, from Abu Said al-Khudari, page or ID: 2186

1 - Ismail Ibrahim Mohamed Badr (1990) an experimental study of the effect of treatment in the sense of reducing the level of alienation among university youth. Ph.D . Faculty of Education in Benha. Zagazig University .

1 - Ashraf Mohamed Abdel Halim (2003). Effectiveness of some existential treatment girls to reduce depression in elderly sample, Master Thesis, College of Education, Umm Al-Qura.

2 - Ashraf Mohamed Abdel Halim (2007), the effectiveness of the treatment program in the sense of reducing the anxiety of death among a sample of young people, doctoral thesis, Faculty of Education, University of AlJazeer.

3- Iman Fawzi (1992), a critical study of the theoretical foundations of existential therapy, $\mathrm{PhD}$ thesis, Faculty of Education, Ain Sham

4 - Hamid Abdel Salam Zahran (1997), mental health and psychotherapy, 3rd floor, Cairo, the world of books.

5 - Hamed Salam Zahran (1980), the effectiveness of treatment in the sense as a guiding method in the reduction of some behavioral disorders in adolescence, doctoral thesis, Institute of Childhood Studies, Ain Shams University.

6. Sayed Sobhy (1983), Youth and the Crisis of Expression (Psychological Study of Some Problems of Egyptian Youth), Cairo, Modern Commercial Press.

7 - Salah Fouad Mohamed Makkawi (2015), the effectiveness of the treatment program in the sense of reducing the level of depression in a sample of university youth, doctoral thesis, Faculty of Education, Ain Shams University.

8- Abdul Rahman Badawi (1961), a study in the existential philosophy, Cairo, Sudan Publishing House.

\section{REFERENCES}

1- Frankl, E,V , (1967), psychotherapy and existentialism, New-York : Penguin books 1- Ali Abdel Moaty (1997), Media of Modern Philosophy, 2nd floor, c 2 , Alexandria, University of Knowledge.

2- 2 - Victor Frankel (1982), the human search for meaning, translation Talaat Mansour, Kuwait, Dar Al-Qalam.

3- 3 - Louis Kamel Malika (1990), psychological analysis and the human approach, Cairo:Egyptian Renaissance.

4- 4 - Maryhalhal Ben Gerges (1995), the existential meaning and its relationship to some personal variables (a field study on a sample of university youth), Master Thesis, Girls College:Ain Shams University.

5- Second:Foreign References:publishers

6- Lantz , jin , Gomia , Libby (1995), Activities and stages in existential psychotherapy with older adults , Journal of clinical greontology, 16, 1,31-40.

7- Rollomay (1993), The discovery of being (writings is existential psychology) London: Norton company publishers .

8- Yalom ,D.lrvin (1980) existential psychotherapy , New-York : basic books publishers 